\title{
Nano-/microfiber scaffold for tissue engineering: Physical and biological properties
}

\author{
Bianca Palma Santana, ${ }^{1}$ Gian Francesco dos Reis Paganotto, ${ }^{2}$ Fernanda Nedel, ${ }^{2}$ \\ Evandro Piva, ${ }^{1}$ Rodrigo Varella de Carvalho, ${ }^{3}$ Jacques Eduardo Nör, ${ }^{4}$ Flávio Fernando Demarco, ${ }^{1}$ \\ Neftali Lenin Villarreal Carreño ${ }^{2}$ \\ ${ }^{1}$ Department of Operative Dentistry School of Dentistry, Federal University of Pelotas, Pelotas, RS, Brazil \\ ${ }^{2}$ Technology Development Center, Federal University of Pelotas, Pelotas, RS, Brazil \\ ${ }^{3}$ Department of Operative Dentistry School of Dentistry, University of Paraná, Paraná, PR, Brazil \\ ${ }^{4}$ Department of Cardiology, Restorative Sciences, and Endodontics, of the University of Michigan School of Dentistry and the \\ Department of Biomedical Engineering, University of Michigan College of Engineering in Ann Arbor, Michigan
}

Received 7 February 2012; revised 27 March 2012; accepted 25 April 2012

Published online 19 June 2012 in Wiley Online Library (wileyonlinelibrary.com). DOI: 10.1002/jbm.a.34242

\begin{abstract}
Alginate hydrogel $(\mathrm{AH})$ has intrinsic physical and biological limitations that hinder its broader application in tissue engineering. We hypothesized that the inclusion of nanofibers in the hydrogel and the use of a biotemplate that mimics nature would enhance the translational potential of alginate hydrogels. In this study, we have shown a method to obtain nano-/microfibers of titanium (nfTD) and hydroxyapatite (nfHY) using cotton as a biotemplate. These fibers were incorporated in the alginate hydrogel and the mechanical characteristics and biological response to these reinforced materials were evaluated. We observed
\end{abstract}

that these nanofibers resembled the structure of natural collagen and did not mediate cell toxicity. The incorporation of nfTD or nfHY to the AH has not increased the viscosity of the hydrogel. Therefore, this is a feasible method to produce a scaffold with improved physical characteristics, while at the same time generating an enhanced environment for cell adhesion and proliferation. (c) 2012 Wiley Periodicals, Inc. J Biomed Mater Res Part A: 100A: 3051-3058, 2012.

Key Words: tissue engineering, alginate hydrogel, scaffolds, titanium, hydroxyapatite

How to cite this article: Santana BP, dos Reis Paganotto GF, Nedel F, Piva E, de Carvalho RV, Nör JE, Demarco FF, Carreño NLV. 2012. Nano-/microfiber scaffold for tissue engineering: Physical and biological properties. J Biomed Mater Res Part $A$ 2012:100A:3051-3058.

\section{INTRODUCTION}

The interplay of three essential components-scaffolds, responsive cells, and morphogens-constitute the grounding for tissue engineering. ${ }^{1,2}$ Scaffolds can be built by synthetic polymers that provide a better control of physicochemical properties, including degradation rate, microstructure, and mechanical strength. ${ }^{3}$ Natural polymers are advantageous once the structures contain information (e.g., amino acid sequences); they facilitate cell attachment or maintenance of differentiated functions. ${ }^{1}$ The development of highly biocompatible injectable scaffolds would certainly accelerate the translation of tissue engineering to the clinic.

The physical and mechanical properties of scaffolds, including the shape and size of pores, rate of porosity, and pore interconnectivity, play a pivotal role in cell behavior and in tissue formation. ${ }^{1,2}$ In addition, scaffolds should not be only a framework where cells will attach and proliferate, but can also be functionalized with bioactive molecules, such as growth factors, to orientate cell differentiation and guide tissue formation or network vessel development. ${ }^{3}$

Among natural polymers, alginate hydrogel $(\mathrm{AH})$ is an attractive biomaterial, exhibiting biological properties such as biocompatibility and bioactivity derived from its chemical composition, morphology, and structure. AH may be used like beads, or can absorb water and swell readily without dissolving. ${ }^{4}$ In recent years, $\mathrm{AH}$ has found applications in medicine, ${ }^{5}$ pharmacology, ${ }^{6}$ biological science, ${ }^{7}$ dentistry, ${ }^{8}$ and have been used on a large scale in tissue engineering (TE). ${ }^{9,10}$

Recently, it has been demonstrated that nano-/microfiber combined scaffolds could produce an impact on the development of new tissues. Innovative structures with a nano-network closely resemble the extracellular matrix, improving cell adhesion. The microfiber mesh also provides

Correspondence to: B. P. Santana; e-mail: biancapalmasantana.mg@gmail.com

Contract grant sponsors: Conselho Nacional de Desenvolvimento Científico e Tecnológico-CNPq; Coordenação de Aperfeiçoamento de Pessoal de Nível Superior-CAPES; Financiadora de Estudos e Projetos-FINEP; Fundação de Apoio a Pesquisa do Estado do Rio Grande do SulFAPERGS 
mechanical support, with favorable pore size formation, controlled pore format, and increased interconnectivity of the 3D scaffolds; these are important parameters for cell survival, proliferation, and secretion. ${ }^{11,12}$

Biotemplates have attracted interest in synthesizing microcellular ceramic materials, ${ }^{13}$ and biological materials such as cotton, ${ }^{14}$ wood, ${ }^{15}$ paper, ${ }^{16}$ and bacteria. ${ }^{17}$ These materials are abundant, renewable, and almost inexpensive. They could be used as templates to mimic nature, while implementing new technology. The incorporation of titanium dioxide (TD) and hydroxyapatite (HY) used in various sizes and shapes, commercial or synthesized in laboratories, may improve the surface characteristics of 3D scaffolds, with higher porosity rates, more porous uniformity, and higher interconnectivity. ${ }^{18}$

Despite the promising results observed when using alginate hydrogel, the possibility to use a biotemplate and incorporating nano-/micro-fibers could improve the prospects of using $\mathrm{AH}$ in tissue engineering. Here we evaluated a new methodology for synthesizing titanium dioxide and hydroxyapatite based on a precursor method. This technique allows the deposition of a precursor solution in a natural template. Then the fibers obtained by thermal treatment are combined with alginate hydrogel and characterized to observe the biologic properties of this material in tissue engineering.

\section{MATERIALS AND METHODS}

\section{Preparation of titanium dioxide resin and fibers}

Figure 1 is a flowchart summarizing the methods employed here. The resin preparation of titanium dioxide (TD) was synthesized by a polymeric precursor method based on others' research. ${ }^{19}$ We used a ratio of 3 moles of acid to 1 mole of metal. We used citric acid on a $57.64 \mathrm{~g}$ mass and mixed with $45 \mathrm{~mL}$ of distilled water until homogenization, forming solution $\mathrm{A}$. We mixed titanium isopropoxide (28.43 g or $29.91 \mathrm{~mL}$ ) with solution A to form solution B. Solution B was stirred for $4 \mathrm{~h}$, then ethylene glycol $(34.27 \mathrm{~mL})$ was incorporated at a ratio of $40 \%$ ethylene glycol $60 \%$ citric acid $(\mathrm{m} / \mathrm{w})$ and stirred until homogenized. All mixtures were shaken at a temperature of $90^{\circ} \mathrm{C}$, forming the final solution $\mathrm{C}$, which was ready to be impregnated with the organic fibers. We selected cotton as the biotemplate material. The resin impregnation into the organic fiber (cotton) was accomplished with the aid of a pipette dripping the solution evenly over the fibers (Fig. 2), and cotton was fixed on a pedestal with a paper filter, so the excess resin could be removed by gravity. After drawing the excess, the fiber was dried at $90^{\circ} \mathrm{C}$ for $2 \mathrm{~h}$, then taken to a furnace and calcined at thermal treatments $\left(800,1000\right.$, and $\left.1200^{\circ} \mathrm{C}\right)$ for $5 \mathrm{~h}$, respectively, obtaining the nano-/microfibers of titanium dioxide (nfTi).

\section{Preparation of hydroxyapatite resin and fibers}

The resin preparation of hydroxyapatite (HY) was synthesized by a polymeric precursor method similar to the process we used for the titanium dioxide fibers. The resin method is also described in the literature. ${ }^{20}$ We prepared a ratio of 4 moles of acid to 1 mole of metal. We weighed citric

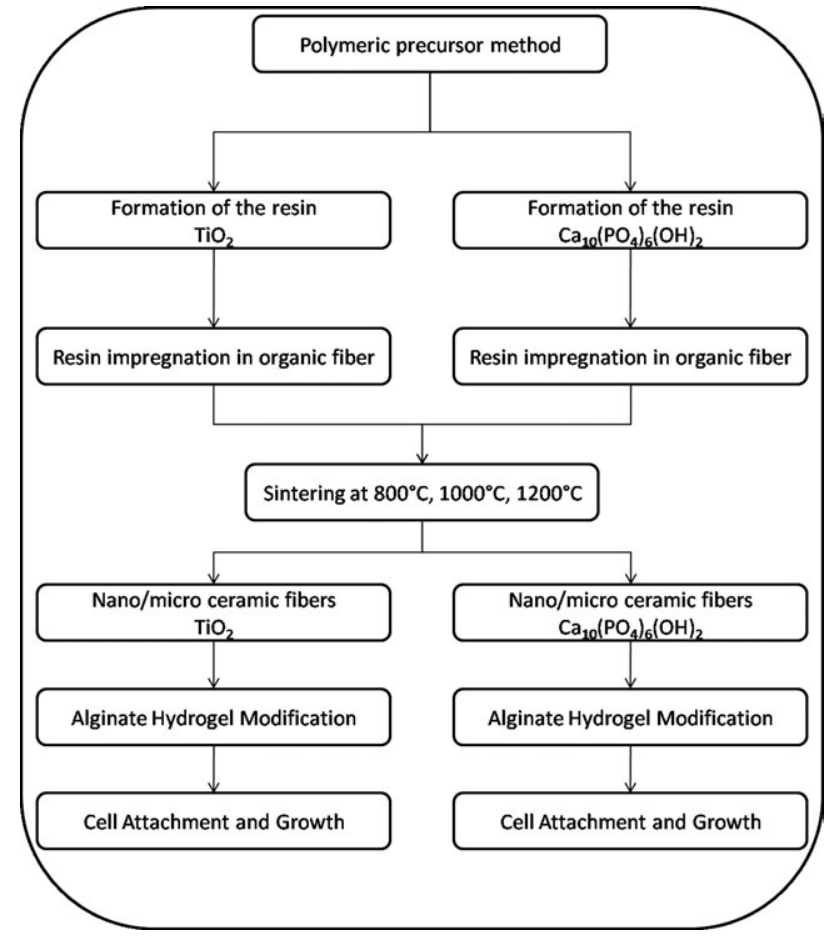

FIGURE 1. Schematic of the experiment steps for fabricating nano/ micro fibers of TD and HA by the biotemplating process, alginate hidrogel modification, and cell attachment and growth.

acid on a precision scale (38.34 g) and mixed it with $100 \mathrm{~mL}$ of distilled water until homogenization to form solution A. The calcium nitrate $(11.80 \mathrm{~g})$ and ammonium phosphate (3.96 g) were weighed, added, and stirred into the solution until homogeneous to form solution B. Then we added ethylene glycol (25.56 g), according to the ratio $40 \%$ ethylene gly$\mathrm{col} / 60 \%$ citric acid $(\mathrm{w} / \mathrm{w})$ and stirred until homogenization, at a temperature of $45^{\circ} \mathrm{C}$, forming the solution $\mathrm{C}$ that was ready to be impregnated on the organic fiber (cotton). The impregnation of resin into the organic fiber was similar to the process previously described for titanium dioxide. After removing the excess, the fiber was kiln-dried at $90^{\circ} \mathrm{C}$ for $8 \mathrm{~h}$, then taken to a furnace and calcined at thermal treatments $\left(800,1000\right.$, and $\left.1200^{\circ} \mathrm{C}\right)$ for $5 \mathrm{~h}$, respectively, obtaining the nano-/microfibers of hydroxyapatite (nfHY).

\section{FTIR spectroscopy}

We used infrared spectroscopy to characterize the structure of the nano-/microfibers sintered at different temperatures. The infrared spectra were measured with an FTIR spectrophotometer (Fourier Transform Infrared Spectrophotometer, IRPrestige-21, Shimadzu). Each spectrum of samples was acquired via accumulation of 96 scans with a resolution of $4 \mathrm{~cm}^{-1}$.

\section{X-ray diffraction (XRD)}

XRD patterns of fibers sintered at different temperatures were obtained by an X-ray diffraction meter (XRD, Shimadzu, model XRD-6000). The equipment uses a diffraction 


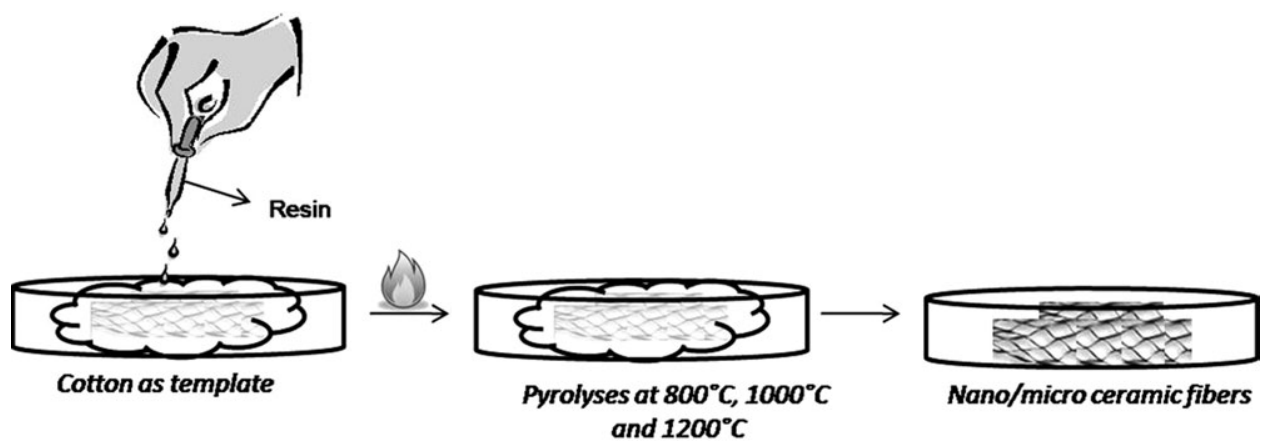

FIGURE 2. Schematic of the resin impregnation in organic fiber, pyrolysis at 800,1000 , and $1200^{\circ} \mathrm{C}$, and the nano/micro metal and ceramic fibers obtention.

tube with a copper target at a wavelength approximately equal to $1.54060 \AA$, with a power of $2 \mathrm{~kW}$, v30 kV current of $30 \mathrm{~mA}$. The analysis was performed in the angle range from $20^{\circ}$ to $80^{\circ}$ for nfTD, and from $10^{\circ}$ to $80^{\circ}$ for nfHY, at a speed of $1^{\circ} \min ^{-1}$ in continuous scan.

\section{Cytocompatibility tests of nano/micro fibers}

An immortalized mouse fibroblast cell line (3T3/NIH) was maintained in Dulbecco's Modified Eagle Medium (DMEM) supplemented with 10\% fetal bovine serum (FBS), $2 \%$ L-glutamine, penicillin (100 $\left.\mathrm{U} \mathrm{mL}^{-1}\right)$, and streptomycin (100 mg mL ${ }^{-1}$ ) (GIBCO-BRL, Grand Island, NY). Mouse fibroblasts were maintained as a stock culture in DMEM and incubated at $37^{\circ} \mathrm{C}$ in a humidified atmosphere of $5 \%$ $\mathrm{CO}_{2}$ in air until subconfluency was reached. The fibers were weighed and mixed in culture medium (DMEM-supplemented with $10 \%$ fetal bovine serum-FBS) as follows: nfTD (molecular weight $=79.87 \mathrm{~g} \mathrm{~mol}^{-1}$ ), so $79.87 \times$ $0.01 M / 1 M=0.7987 ; X=0.7987(0.7987 \mathrm{~g}$ to obtain $1 \mathrm{~L}$ of titanium dioxide $(10 \mathrm{mM})$ solution in DMEM); and the stock solution-obtaining $10 \mathrm{~mL}$ of titanium dioxide $(10 \mathrm{mM})$ : $0.7987 \times 0.01 \mathrm{~L} / 1 \quad \mathrm{~L}, \quad X=0.007987-0.00799$. Thus, $0.00799 \mathrm{~g}$ of nfTD were weighed and mixed in a culture medium (DMEM), to obtain $10 \mathrm{~mL}$ of nfTD $(10 \mathrm{mM})$. The same calculation was used to obtain $10 \mathrm{~mL}$ of nfHY (molecular weight $\left.=1004.63 \mathrm{~g} \mathrm{~mol}^{-1}\right)$ solution $(10 \mathrm{mM})$. To produce different tested concentrations (10-0.001 $\mathrm{mM}$ ) five serial dilutions $(10 \times)$ were made.

We incubate the cells in a 96-well plate $\left(2 \times 10^{4}\right.$ cells per well) in contact with the products for the evaluation of cytotoxicity for $24 \mathrm{~h}$ at $37^{\circ} \mathrm{C}$ in a humidified atmosphere with $5 \%$ of $\mathrm{CO}_{2}$. The 3-(4,5-dimethylthiazol-2-yl)-2,5-diphenyltetrazolium bromide (MTT) assay (Sigma Chemical Company, St. Louis, MO) was used to assess cell metabolic function by mitochondrial dehydrogenase activity. After removing the products, we washed the cells with phosphate-buffered saline (PBS), and then added $180 \mu \mathrm{L}$ of the medium to $20 \mu \mathrm{L}$ of MTT solution (5 mg of MTT/mL PBS) were added to each well. After $5 \mathrm{~h}$ of incubation at $37^{\circ} \mathrm{C}$ in darkness the blue formazan precipitate was extracted from the mitochondria using $200 \mu \mathrm{L} /$ well dimethyl sulfoxide (DMSO) on a shaker for $5 \mathrm{~min}$ at $150 \mathrm{rpm}$. The absorption was determined spectrophotometrically at $540 \mathrm{~nm}$. All experiments were carried out in triplicate. Data were submitted to one-way ANOVA and Tukey post hoc tests, with $p<0.05$.

\section{Morphological analysis}

The nfTD and nfHY were crushed gently, gold-sputtered further on the structures and the diameters were investigated using a scanning electron microscope (Shimadzu SSX550-Japan).

\section{Hydrogel modification}

Sodium alginate $\left(\mathrm{NaC}_{6} \mathrm{H}_{7} \mathrm{O}_{6}\right.$-Vetec Química Fina Ltda) was dissolved in deionized water and mixed with calcium sulfate $\left(\mathrm{CaSO}_{4} \cdot 2 \mathrm{H}_{2} \mathrm{O}\right.$-Vetec Química Fina Ltda) forming the ionic cross-linking ${ }^{20,21}$ or the hydrogel (2 wt \%). The nano-/micro-fibers of titanium dioxide and hydroxyapatite calcined at $1200^{\circ} \mathrm{C}$ were kept a constant concentration of $0.07 \% \mathrm{~g} \mathrm{~mL}^{-1}$ and they were added to the hydrogel under magnetic stirring. The scaffold architectures before and after adding the nano-/micro-fibers were characterized using scanning electron microscopy (SEM). The hydrogel was placed in a 24-well plate. Hydrogel samples with titanium dioxide and with hydroxyapatite were frozen in a refrigerator at $-60^{\circ} \mathrm{C}$ for $24 \mathrm{~h}$, and lyophilized in a freeze drier. Then the dry scaffold was coated with gold-sputtered and analyzed by SEM in $15 \mathrm{kV}$.

\section{Viscosity measurement}

After being modified with the nano-/micro-fibers, the viscosity of hydrogel was measured by the Brookfield DV-II + Pro Viscometers (USA) with a constant shear rate. The total volume measured was $10 \mathrm{~mL}$. The gel was placed in the rheometer and the rheological test lasted for $3 \mathrm{~min}$.

\section{Attachment and proliferation of the cells in hydrogel}

For the preliminary studies on the attachment and proliferation of the cells, three replicas from all materials were incubated with 3 T3 cells in a 24 -well plate $(2 \times 104$ cells per well) for 3,6 , and $24 \mathrm{~h}$. After the incubation periods, the cell/hydrogel constructs were prepared using a freezing and lyophilizing method. $^{22}$ The 24-well cell/hydrogel 

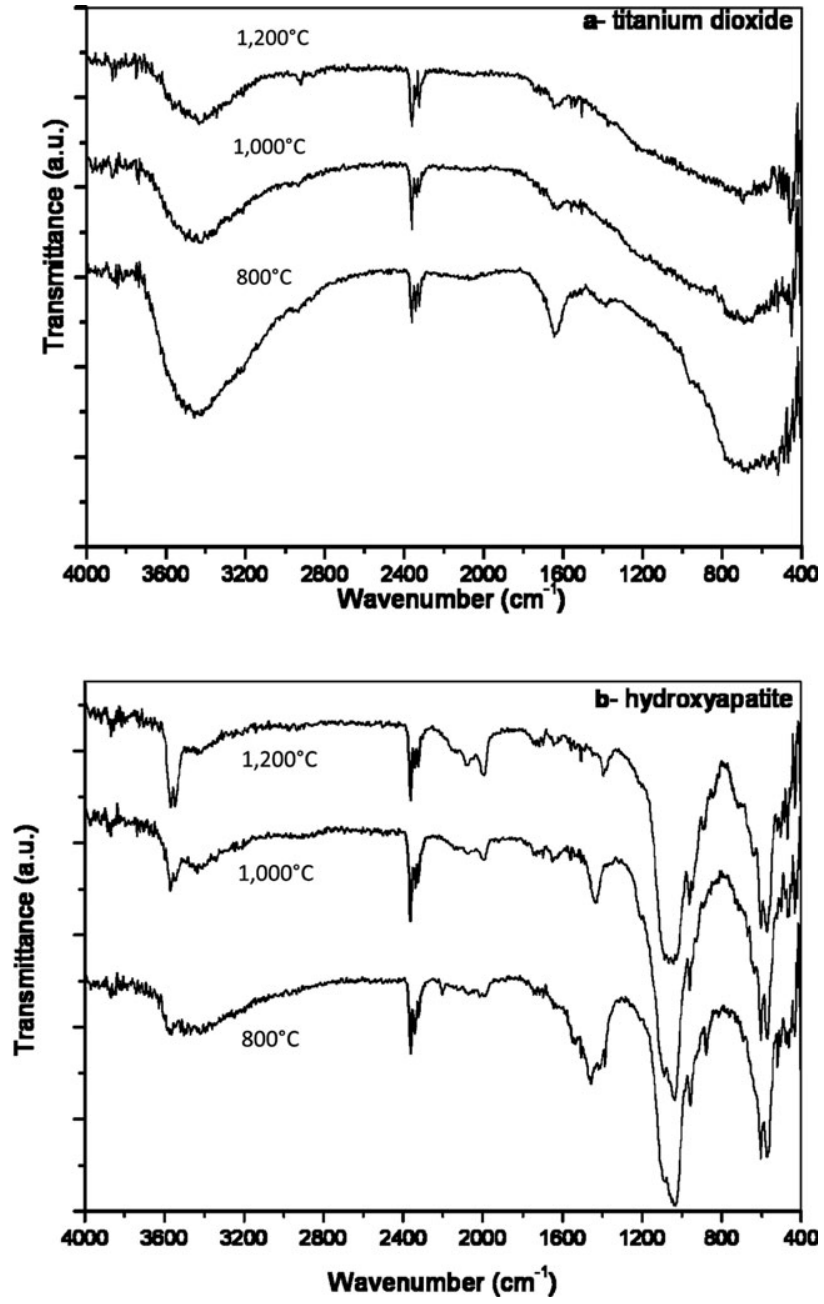

FIGURE 3. FTIR spectra of TD (a), HY (b).

scaffold was frozen at $-20^{\circ} \mathrm{C}$ for $3 \mathrm{~h}$, then at $-80^{\circ} \mathrm{C}$ for $24 \mathrm{~h}$. The samples were then lyophilized by freeze-drying (L101, Liobras, Brazil) for $24 \mathrm{~h}$. The dry cell/hydrogel was coated with gold and analyzed by SEM.

\section{RESULTS}

\section{FT-IR analysis}

The FTIR spectra of cotton-derived TD and HY sintered at 800,1000 , and $1200^{\circ} \mathrm{C}$ for the specific times shown in the methodologies are given in Figure 3. The FTIR for nfTD [Fig. 3(a)] shows the spectra of different samples calcined in different temperatures. The peaks at about 1620 and $3400 \mathrm{~cm}^{-1}$ are attributed to adsorbed water molecules, and the band at $400-850 \mathrm{~cm}^{-1}$ corresponds to the $\mathrm{Ti}-\mathrm{O}-\mathrm{Ti}$ stretching vibration mode. ${ }^{23}$ The peaks at about 3000, 1497 $\mathrm{cm}^{-1}$ are the $\mathrm{C}-\mathrm{H}$ and $\mathrm{C}=\mathrm{C}$ stretching vibration mode in the aromatic ring; the peak at about $530 \mathrm{~cm}^{-1}$ results from the $\mathrm{Ti}-\mathrm{O}$ in the $\mathrm{TiO}_{2}$ lattice; and the peaks at about 400 and $700 \mathrm{~cm}^{-1}$ are closely related to the vibration mode of $\mathrm{Ti}-\mathrm{O}$ in the rutile-phase $\mathrm{TiO}_{2}$ lattice. ${ }^{22}$

The nfHY [Fig. 3(b)] demonstrated stretch vibration of hydrogen bonded $\mathrm{O}-\mathrm{H}$ groups in a broad absorption band between 3700 and $3100 \mathrm{~cm}^{-1}$, together with an absorption peak at $1636 \mathrm{~cm}^{-1}$. The characteristic stretching and vibrational modes of structural $0-\mathrm{H}$ groups in nfHY crystallites can be observed in two sharp peaks at 3571 and $632 \mathrm{~cm}^{-1}$ respectively. ${ }^{24}$ The peak at $3642 \mathrm{~cm}^{-1}$ has been reported to be due to the $\mathrm{OH}^{-}$stretching vibrations of $\mathrm{Ca}(\mathrm{OH})_{2}{ }^{25}$ The main characteristic bands at around 1090, 1039, 599, and $571 \mathrm{~cm}^{-126}$ are clearly observed, showing typical apatite characteristics. The bands located at $602,962,900-1300$, and 1950-2200 $\mathrm{cm}^{-1}$ are characteristic of $\mathrm{PO}_{4}^{3-}$. Comparing the results, the peaks in the $\mathrm{nfHY}$ sintered at $1200^{\circ} \mathrm{C}$ became stronger in intensity and better in resolution. These results clearly indicate the formation of a typical HY structure. ${ }^{27}$

\section{XRD analysis}

The XRD results illustrated in Figure 4 display that the crystal phase of titanium dioxide and hydroxyapatite existed in this biotemplate. The results indicated that the polymeric
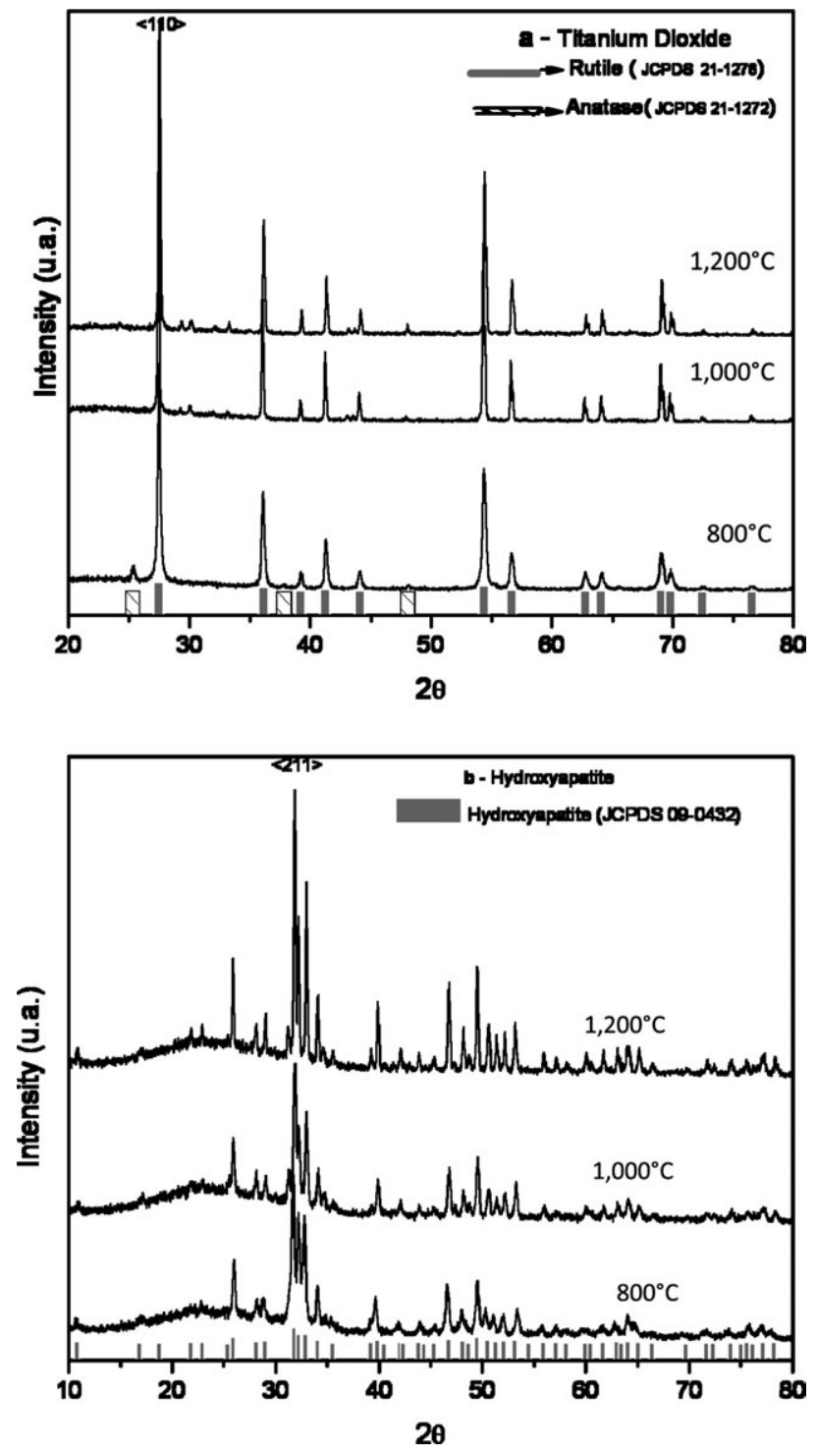

FIGURE 4. XRD patterns of TD (a) and HY (b). 


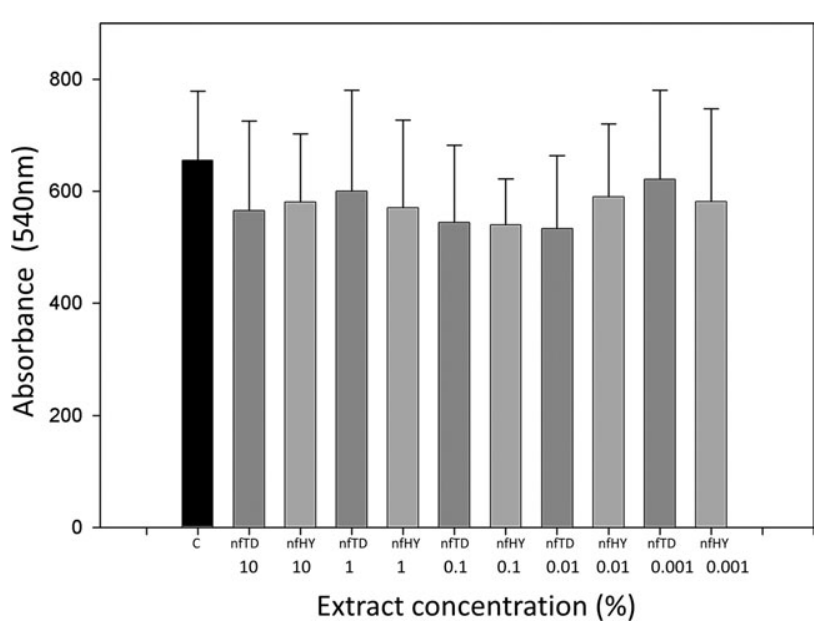

FIGURE 5. The fibers showed no cytotoxicity when compared to the control group (One-way ANOVA and Tukey post hoc tests, with $p<$ 0.05). Mouse fibroblast cell line $(3 \mathrm{~T} 3 / \mathrm{NIH})$ activity (MTT assay) in response to different dilutions ranging from 10 to $0.001 \mathrm{mM}$ from nano/micro fibers of TD and HY [C (control group); T (titanium dioxide); $\mathrm{H}$ (Hydroxyapatite)], and standard deviations of the absorbance at $540 \mathrm{~nm}$ are represented. All experiments were carried out in triplicates.

precursor method (organic-fiber-derived TD and HY, sintered), removed the organic portion, leaving only the TD and HY in nano. The XRD results nfTD in rutile and anatase phases are shown in Figure 4(a). XRD patterns exhibited strong diffraction peaks at $27^{\circ}, 36^{\circ}$, and $55^{\circ}$, above $1000^{\circ} \mathrm{C}$, indicating TD in the rutile phase. At $800^{\circ}$ we observe the diffraction peaks at 25 and $48^{\circ}$, indicating TD in the anatase phase in accordance with previous reports. ${ }^{23}$ All peaks are in good agreement with the standard spectrum number of Joint Committee on Powder Difraction Standards-JCPDS 21-1276 and JCPDS 21-1272.

The XRD results for nfHY are shown in Figure 4(b). All the fibers calcined at different temperatures demonstrate peaks identical to the standard spectrum (JCPDS 09-043), indicating the formation of apatite structures. The crystallinity increased with the sintering temperature up to $1000^{\circ} \mathrm{C}^{25}$ The sample heated at $800^{\circ} \mathrm{C}$ had a grayish color due to the presence of some residual carbon from the template used for the preparation of the fibers. The carbon was removed upon calcinations at $1000^{\circ} \mathrm{C}$ and the fibers were pure white in color. Considering the findings from FTIR and XRD analyses, we have selected nfTD and nfHY sintered at $1200^{\circ} \mathrm{C}$, because better characteristics were observed for the fibers produced at these temperatures.

\section{Nano-/micro fibers cell viability}

The cell viability was confirmed by the MTT method (Fig. 5), where the absorbance values are proportional to the number of viable cells.

\section{Viscosity measurements}

In Table I we can observe the viscosity values for the $\mathrm{AH}$ alone and when the hydrogel was combined with nfTD or nfHY. An increase in viscosity was observed after the nanofillers were added, especially for nfHY particles.

\section{SEM observation}

Figure 6 exhibits SEM images of the fibers obtained after sintering at $1200^{\circ} \mathrm{C}$. These fibers retain the original fibrous cotton morphology, with cotton body removal, thus the nano-/microfiber morphology followed the template of the cotton. The average diameter of the nfTD and nfHY produced was around $400 \mathrm{~nm}$ to $10 \mu \mathrm{m}$ [Fig. 6(a2,b2)]. Figure 6(a3) shows the observations of the surface of the nfTD fibers, which showed furrows, striated surface and were hollow. Figure 6(b3) shows the nfHY fibers examined by Field Emission Gun Scanning Electron Microscope (FEG SEM), demonstrating a snake skin-like surface. Like the nfTD, these fibers were also hollow.

The SEM micrographs of $2 \% \mathrm{AH}, 2 \% \mathrm{AH}$ with nfTD, and $2 \%$ AH with nfHY are presented in Figure 7(a1-c1). Compared with the unreinforced alginate hydrogel [Fig. 7(a1)], the modified alginate hydrogel with nfTD [Fig. 7(b1)] or nfHY [Fig. 7(c1)] exhibits a novel structure for cell attachment and porosities around 100-300 $\mu \mathrm{m}$.

Comparing alginate with nfTD [Fig. 7(b1)] and nfHY [Fig. 7(c1)], we could observe that the alginate with nfHY had more porosity than the others, suggesting that this material could be better. However, during the in vitro proliferation of fibroblasts (3T3). Three hours after seeding, rounded cells could be seen attached to the surface of the materials. In the SEM images it is also possible to see (arrows) cells in cellular division, colonizing the inner surface of the pores, and filopodia extension. After $6 \mathrm{~h}$, larger cytoplasm extensions were visible, and cell proliferation could be observed in all groups. After $24 \mathrm{~h}$, cells were covering almost the entire scaffold surfaces in the three tested scaffolds, demonstrating their ability to allow cell adhesion and proliferation, which are essential requirements for a scaffold material.

\section{DISCUSSION}

The results of our study demonstrated that the reinforcement of alginate hydrogel with nano-/microfibers of titanium or hydroxyapatite, using cotton as the biotemplate, produced scaffolds with new morphological characteristics which seems to be more favorable for cell adhesion and proliferation, disclosing promising potential for tissue regeneration usage.

Several studies have investigated the use of alginate hydrogel, with different applications, such as gels for drug delivery, ${ }^{6,28}$ cell encapsulation material, ${ }^{4,26}$ and injectable

TABLE I. Viscosity of Hydrogel Alginate Combined Nano/ Micro Fibers

\begin{tabular}{|c|c|c|}
\hline Sample & $\begin{array}{c}\text { Temperature } \\
\left({ }^{\circ} \mathrm{C}\right)\end{array}$ & $\begin{array}{l}\text { Viscosity } \\
\left(\mathrm{mPa} \mathrm{s}^{-1}\right)\end{array}$ \\
\hline Alginate hydrogel & $25^{\circ} \mathrm{C}$ & 822,4 \\
\hline Alginate Hydrogel/ $\mathrm{TiO}_{2}$ & $25^{\circ} \mathrm{C}$ & 847,9 \\
\hline Alginate hydrogel/hydroxyapatite & $25^{\circ} \mathrm{C}$ & 948,1 \\
\hline
\end{tabular}



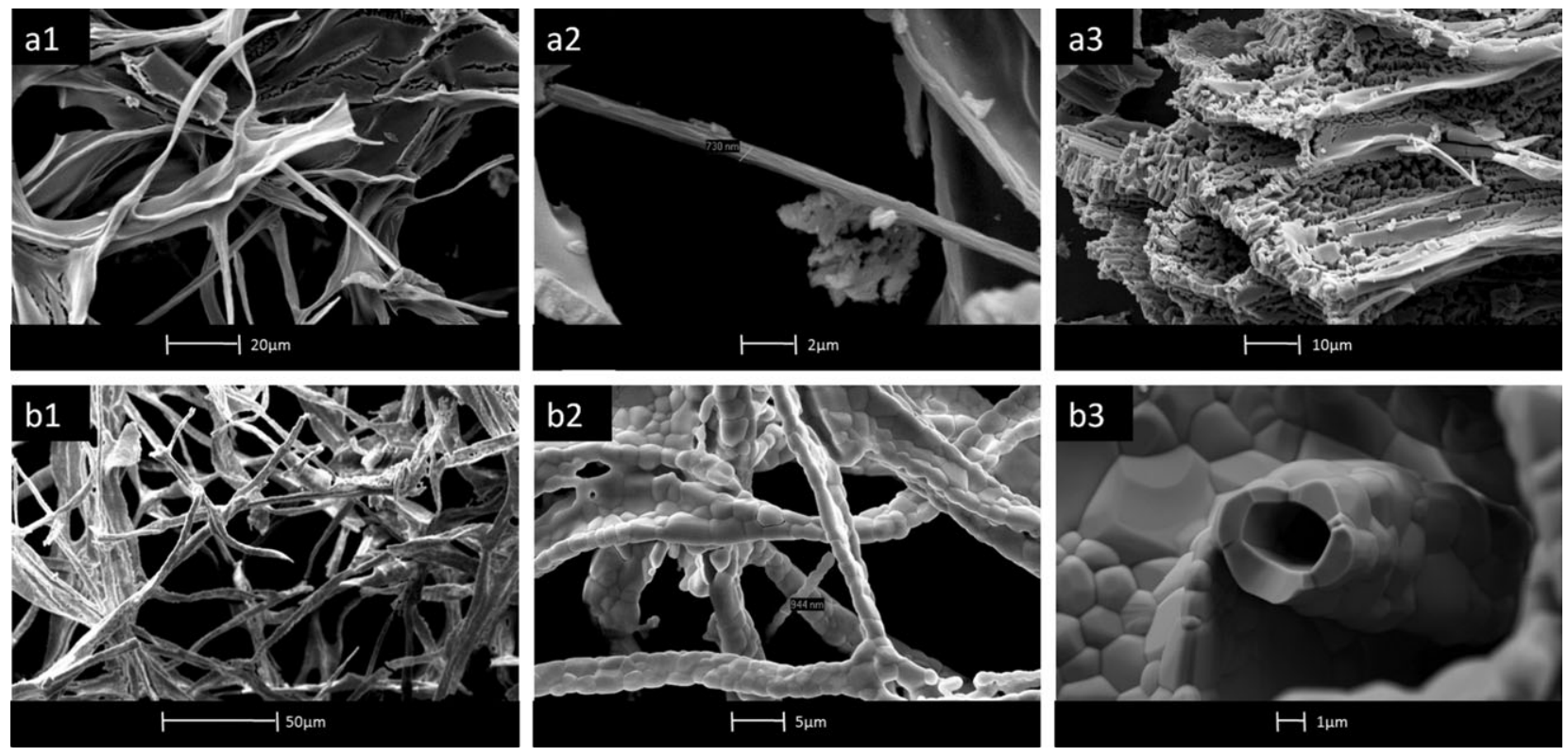

FIGURE 6. a-nano/micro fibers of TD: a3, diameter of $\sim 730 \mathrm{~nm}$; b-nano/micro fibers of hydroxyapatite: b3, diameter of $\sim 868 \mathrm{~nm}$. The samples were calcined at $1200^{\circ} \mathrm{C}$

cell transplantation vehicle. ${ }^{5}$ The intracellular matrix of alginate present mixed salt of various cations found in sea water such as $\mathrm{Mg}^{2+}, \mathrm{Ca}^{2+}, \mathrm{Sr}^{2+}, \mathrm{Ba}^{2+}$, and $\mathrm{Na}^{2+},{ }^{21}$ with building blocks constituted from $\beta$-D-mannuronic and $\alpha$-Lguloronic acids, joined by 1,4 linkages. Generally, studies have demonstrated that material exhibited biocompatibility, low toxicity, and relatively low cost. ${ }^{20}$

In tissue engineering, alginate hydrogel has been applied for cartilage repair, ${ }^{9}$ culture environment, and delivery carriers, ${ }^{10}$ exhibiting the advantage of gelling capacity that can encapsulate various substances with minimal trauma, ${ }^{29}$ absorb water, and swell readily without dissolving. ${ }^{26}$ Diverse techniques and methodologies have been developed to control physical, chemical, and gelling properties to provide a gel with appropriate properties for specific applications, overcoming the disadvantage that $\mathrm{AH}$ is not naturally broken down enzymatically in mammals and has poorly regulated degradation. ${ }^{30}$ Several factors affect cell behavior and affinity on hydrogels. These include the crosslink, the general chemistry of the monomers, gelling conditions (e.g., temperature and $\mathrm{pH}$ ), degradation, and swelling. ${ }^{26,31}$ Alginate hydrogel has been modified by another polymers, ${ }^{32}$ proteins, ${ }^{33}$ peptide, ${ }^{34}$ and growth factors ${ }^{8}$ and have been demonstrated to provide an acceptable environment of adhesion and proliferation.

It is well known that the alteration of the network structure and pore size can modify cell adhesion, morphology, and function. ${ }^{35}$ In this study, a new methodology for synthesizing nano-/micro-fibers of titanium dioxide and hydroxyapatite was described using cotton as the biotemplate. The methodology used in our study is quite different from others, ${ }^{36}$ involving precursor solution impregnation in organic fibers, replicating the organic fibers in the nano-/ microfibers produced. The cytocompatibility of TD and HY have already been proven, ${ }^{18,37,38}$ and the findings from our study demonstrated that neither the nfTD nor the nfHY produced a toxic effect, indicating they could be incorporated in alginate hydrogel for applications in tissue engineering. In our study, we used the MTT assay to test the cell viability. The MTT assay measures the reduction of the tetrazolium component from MTT by viable cells, so the level of the reduction of MTT into formazan can reflect the level of cell metabolism. Several studies have used this method to observe the effect of the new material combination on cell viability and proliferation. ${ }^{15,32}$ It is also important to highlight that the incorporation of these nanofibers, despite the small increase in viscosity values, have not increased significantly this viscosity. ${ }^{39}$

Biotemplates are used to mimic nature, while implementing new technology, ${ }^{15}$ providing a favorable environment for cell adhesion and proliferation. We observed that the methodology in our study-replacing the cotton for the nanofibers, either from hydroxyapatite or titaniumwas capable of removing the organic structure from cotton, while maintaining the physical structure of this natural template. The size of the nanofibers formed using the cotton biotemplate closely resembled the diameter of collagen fibers found in the extracellular matrix, with sizes varying between 50 and $500 \mathrm{~nm}^{40}$ This fibrilar characteristic is important for cell attachment, proliferation, and differentiated function in tissue engineering approaches. $^{3}$

Titanium dioxide and hydroxyapatite are biomaterials that have been used in tissue engineering, ${ }^{18,37,38}$ and under SEM examination (Fig. 7) we observed that the combination of alginate hydrogel with the nano-/microfibers create a new gel with more pores and interconnectivity, which are key features when looking for an ideal scaffold. ${ }^{3,11,12}$ The 

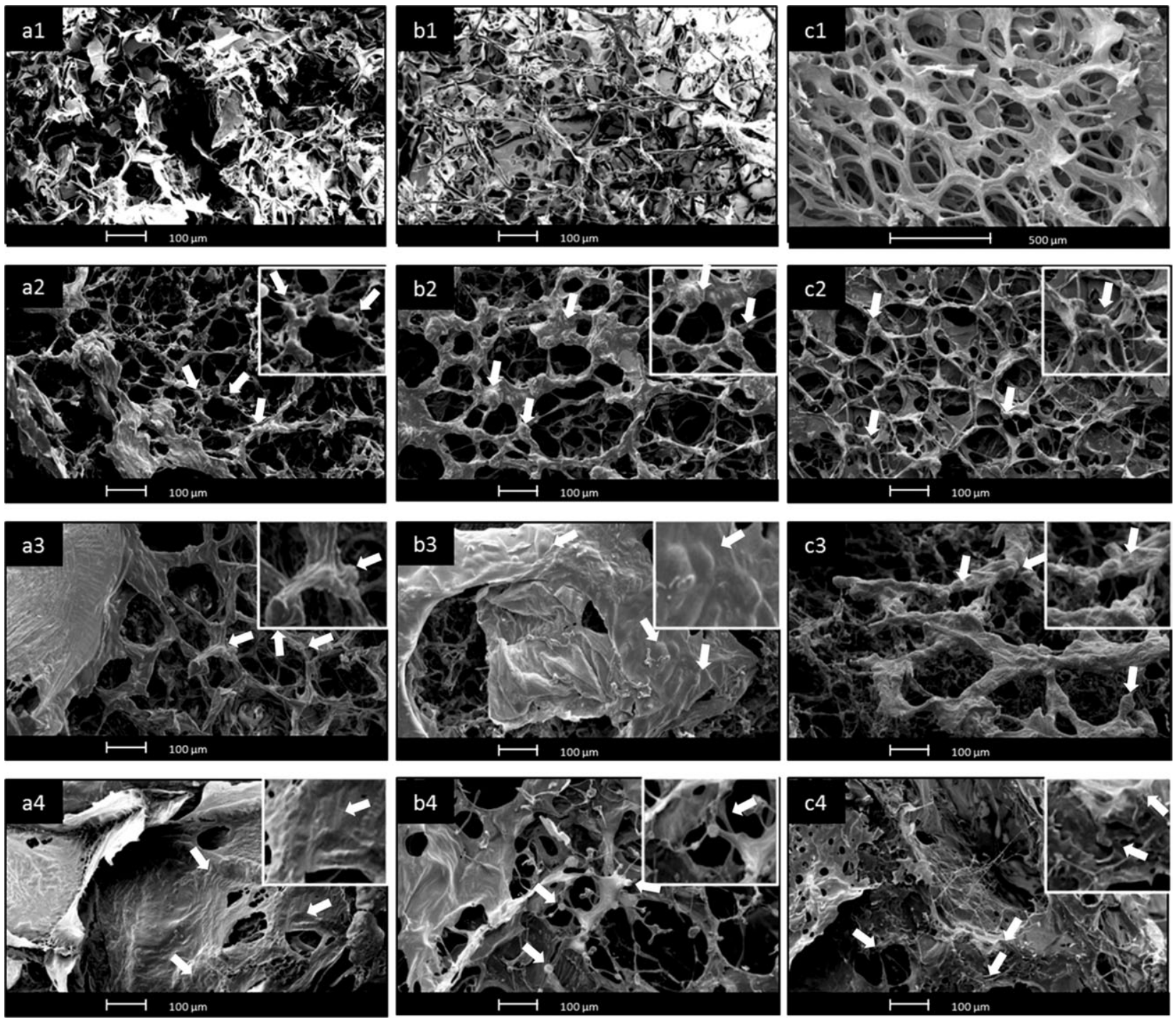

FIGURE 7. SEM micrographs at $\times 100$ magnification: alginate hydrogel $2 \%$ untreated (a: $1-4$ ), and treated with nfTD (b: $1-4$ ), and nfHY (c: $1-4)$. In the micrographs numbered at 2,3 , and 4 , we observe the cell/scaffold after 3, 6, and $24 \mathrm{~h}$, respectively.

alginate hydrogel treated with nfHY showed an improved morphology due to the higher porosity produced, with a higher cell adhesion and proliferation when compared to the group with nfTD or the hydrogel alone. Hydroxyapatite is well known for its cytocompatibility and is used in a series of different biological applications. ${ }^{41,42}$ However, it is noteworthy that after $24 \mathrm{~h}$, cells almost covered the entire scaffold structure, indicating that the alginate hydrogel with or without nanofiber inclusion is a favorable environment for cell growth, corroborating previous reports in the literature. $^{4,30,43}$ Nevertheless, we should emphasize that the increased porosity observed for hydrogels with nanofiber incorporation could play a significant role in the initial moments when scaffolds are applied in tissue engineering, which are critical for the ability of cells to attach and then proliferate. $^{44}$ The observed improved porosity can also be favorable for initial vascularization, ${ }^{45}$ and angiogenesis plays a crucial role in the maintaining of initial tissue regenera- tion. $^{3}$ The regeneration of specific tissues aided by synthetic materials has been shown to be dependent on the porosity and pore size of the supporting three-dimensional structure. $^{46}$

Additional studies are been carried out in our laboratory to investigate the potential of these new reinforced hydrogels and the possibility to functionalize them with morphogenic agents to produce an even better material.

\section{CONCLUSION}

Here we described a method to obtain hollow nano-/ microfibers which could be incorporated in alginate hydrogel, producing a material that could be useful for tissue engineering application as an injectable material. The inclusion of nanofibers which did not increase cell toxicity or viscosity produced hydrogels with higher and more structured porosities that provide a favorable environment for cell adhesion and proliferation. 


\section{REFERENCES}

1. Demarco FF, Casagrande L, Zhang Z, Dong Z, Tarquinio SB, Zeitlin BD, et al. Effects of morphogen and scaffold porogen on the differentiation of dental pulp stem cells. J Endod 2010;36: 1805-1811.

2. Yang S, Leong KF, Du Z, Chua CK. The design of scaffolds for use in tissue engineering. Part I. Traditional factors. Tissue Eng 2001; 7:679-689.

3. Demarco FF, Conde MCM, Cavalcanti BN, Casagrande L, Sakai VT, Nör JE. Dental pulp tissue engineering. Braz Dent J 2011;22: 3-14.

4. Rowley JA, Madlambayan G, Mooney DJ. Alginate hydrogels as synthetic extracellular matrix materials. Biomaterials 1999;20:45-53.

5. Novikova LN, Mosahebi A, Wiberg M, Terenghi G, Kellerth JO, Novikov LN. Alginate hydrogel and matrigel as potential cell carriers for neurotransplantation. J Biomed Mater Res A 2006;77: 242-252.

6. Tonnesen $\mathrm{HH}$, Karlsen J. Alginate in drug delivery systems. Drug Dev Ind Pharm 2002;28:621-630.

7. Sone T, Nagamori E, Ikeuchi T, Mizukami A, Takakura Y, Kajiyama $S$, et al. A novel gene delivery system in plants with calcium alginate micro-beads. J Biosci Bioeng 2002;94:87-91.

8. Dobie K, Smith G, Sloan AJ, Smith AJ. Effects of alginate hydrogels and TGF-beta 1 on human dental pulp repair in vitro. Connect Tissue Res 2002;43:387-390.

9. Chen YB, Bilgen B, Pareta RA, Myles AJ, Fenniri H, Ciombor DM et al. Self-Assembled Rosette Nanotube/Hydrogel Composites for Cartilage Tissue Engineering. Tissue Eng Part C Methods. 2010;16:1233-1243.

10. Lee KY, Mooney DJ. Alginate: Properties and biomedical applications. Prog Polym Sci 2012;37:106-126.

11. Woo KM, Chen VJ, Ma PX. Nano-fibrous scaffolding architecture selectively enhances protein adsorption contributing to cel attachment. J Biomed Mater Res A 2003:67:531-537.

12. Tuzlakoglu K, Bolgen N, Salgado AJ, Gomes ME, Piskin E, Reis RL. Nano- and micro-fiber combined scaffolds: A new architecture for bone tissue engineering. J Mater Sci Mater Med 2005;16: 1099-1104.

13. Yan J, Wu G, Li L, Yu A, Sun X, Guan N. Synthesis of uniform TiO2 nanoparticles with egg albumen proteins as novel biotemplate. J Nanosci Nanotechnol. 2010;10:5767-5775.

14. Fan $T$, Sun $B, G u J$, Zhang $D$, Lau LWM. Biomorphic $\mathrm{Al}_{2} \mathrm{O}_{3}$ fibers synthesized using cotton as bio-templates. Script Mater 2005;53: 893-897.

15. Gonzalez P, Borrajo JP, Serra J, Chiussi S, Leon B, Martinez-Fernandez $\mathrm{J}$, et al. A new generation of bio-derived ceramic materials for medical applications. J Biomed Mater Res A 2009;88: 807-813.

16. Popovska N, Streitwieser DA, Xu C, Gerhard H. Paper derived biomorphic porous titanium carbide and titanium oxide ceramics produced by chemical vapor infiltration and reaction (CVI-R). J Eur Ceram Soc 2005;25:829-836.

17. Lagziel-Simis S, Cohen-Hadar N, Moscovich-Dagan H, Wine $Y$, Freeman A. Protein-mediated nanoscale biotemplating. Curr Opin Biotechnol 2006;17:569-573.

18. Rani VVD, Ramachandran R, Chennazhi KP, Tamura H, Nair SV, Jayakumar R. Fabrication of alginate/nanoTiO2 needle composite scaffolds for tissue engineering applications. Carbohydrate Polymers. 2011;83:858-864

19. Leite ER, Carrepo NLV, Santos LPS, Rangel JH, Soledade LEB, Longo $\mathrm{E}$, et al. Photoluminescence in amorphous $\mathrm{TiO}_{2}-\mathrm{PbO}$ systems. Appl Phys A Mater Sci Process 2001;73:567-569.

20. Park H, Kang SW, Kim BS, Mooney DJ, Lee KY. Shear-reversibly crosslinked alginate hydrogels for tissue engineering. Macromol Biosci. 2009;9:895-901.

21. Gombotz W, Wee SF. Protein release from alginate matrices. Adv Drug Deliv Rev 1998;31:267-285.

22. Liqiang J, Honggang F, Baiqi W, Dejun W, Baifu X, Shudan L, et al. Effects of Sn dopant on the photoinduced charge property and photocatalytic activity of $\mathrm{TiO}_{2}$ nanoparticles. Appl Catal B Environ 2006;62:282-291.

23. Xie M, Jing L, Zhou J, Lin J, Fu H. Synthesis of nanocrystalline anatase $\mathrm{TiO}_{2}$ by one-pot two-phase separated hydrolysis-solvothermal processes and its high activity for photocatalytic degradation of rhodamine B. Journal of hazardous materials. 2010;176:139-145.

24. Stoch A, Jastrzejbski W, Dlugon E, Lejda W, Trybalska B, Stoch GJ, et al. Sol-gel derived hydroxyapatite coatings on titanium and its alloy Ti6Al4V. J Mol Struct 2005;744-747:633-640.

25. Ramanan SR, Venkatesh R. A study of hydroxyapatite fibers prepared via sol-gel route. Mater Lett 2004;58:3320-3323.

26. Jen AC, Wake MC, Mikos AG. Review: Hydrogels for cell immobilization. Biotechnol Bioeng 1996;50:357-364.

27. Qian J, Kang Y, Zhang W, Li Z. Fabrication, chemical composition change and phase evolution of biomorphic hydroxyapatite. J Mater Sci Mater Med 2008;19:3373-3383.

28. Yu CY, Zhang XC, Zhou FZ, Zhang XZ, Cheng SX, Zhuo RX. Sustained release of antineoplastic drugs from chitosan-reinforced alginate microparticle drug delivery systems. Int J Pharm 2008;357: 15-21.

29. Klöck G, Pfeffermann A, Ryser C, Gröhn P, Kuttler B, Hahn H-J, et al. Biocompatibility of mannuronic acid-rich alginates. Biomaterials 1997;18:707-713.

30. Augst AD, Kong HJ, Mooney DJ. Alginate hydrogels as biomaterials. Macromol Biosci 2006;6:623-633.

31. Lee KY, Mooney DJ. Hydrogels for tissue engineering. Chem Rev 2001;101:1869-1879.

32. Kievit FM, Florczyk SJ, Leung MC, Veiseh O, Park JO, Disis ML, Zhang M. Chitosan-alginate 3D scaffolds as a mimic of the glioma tumor microenvironment. Biomaterials. 2010;31:5903-5910.

33. Sultzbaugh KJ, Speaker TJ. A method to attach lectins to the surface of spermine alginate microcapsules based on the avidin biotin interaction. J Microencapsulation 1996;13:363-376.

34. Lee JW, Park YJ, Lee SJ, Lee SK, Lee KY. The effect of spacer arm length of an adhesion ligand coupled to an alginate gel on the control of fibroblast phenotype. Biomaterials. 2010;31:5545-5551.

35. Oxley HR, Corkhill PH, Fitton JH, Tighe BJ. Macroporous hydrogels for biomedical applications: Methodology and morphology. Biomaterials 1993;14:1064-1072.

36. Varma HK, Suresh Babu S. Synthesis of calcium phosphate bioceramics by citrate gel pyrolysis method. Ceram Int 2005;31: 109-114.

37. Langer R, Vacanti JP. Tissue engineering. Science 1993;260: 920-926.

38. Tolga Demirtas T, Karakecili AG, Gumusderelioglu M. Hydroxyapatite containing superporous hydrogel composites: Synthesis and in-vitro characterization. J Mater Sci Mater Med 2008;19: 729-735.

39. Tan R, Niu X, Gan S, Feng Q. Preparation and characterization of an injectable composite. J Mater Sci Mater Med 2009:20: $1245-1253$.

40. Elsdale T, Bard J. Collagen substrata for studies on cell behavior J Cell Biol 1972;54:626-637.

41. Guo Y-P, Guo L-H, Yao Y-b, Ning C-Q, Guo Y-J. Magnetic mesoporous carbonated hydroxyapatite microspheres with hierarchical nanostructure for drug delivery systems. Chemical Communications. 2011;47:12215-12217.

42. Iafisco M, Varoni E, Di Foggia M, Pietronave S, Fini M, Roveri N, et al. Conjugation of hydroxyapatite nanocrystals with human immunoglobulin $\mathrm{G}$ for nanomedical applications. Colloids and Surfaces B: Biointerfaces. 2012:90:1-7.

43. Kolambkar YM, Dupont KM, Boerckel JD, Huebsch N, Mooney DJ, Hutmacher DW, et al. An alginate-based hybrid system for growth factor delivery in the functional repair of large bone defects. Biomaterials 2011;32:65-74.

44. Casagrande L, Demarco FF, Zhang Z, Araujo FB, Shi S, Nör JE. Dentin-derived BMP-2 and odontoblast differentiation. J Dent Res. 2010;89:603-608.

45. Roosa SMM, Kemppainen JM, Moffitt EN, Krebsbach PH, Hollister SJ. The pore size of polycaprolactone scaffolds has limited influence on bone regeneration in an in vivo model. Journal of Biomedical Materials Research Part A. 2010;92A:359-368.

46. Cima LG, Vacanti JP, Vacanti C, Ingber D, Mooney D, Langer R. Tissue engineering by cell transplantation using degradable polymer substrates. J Biomech Eng 1991;113:143-151. 